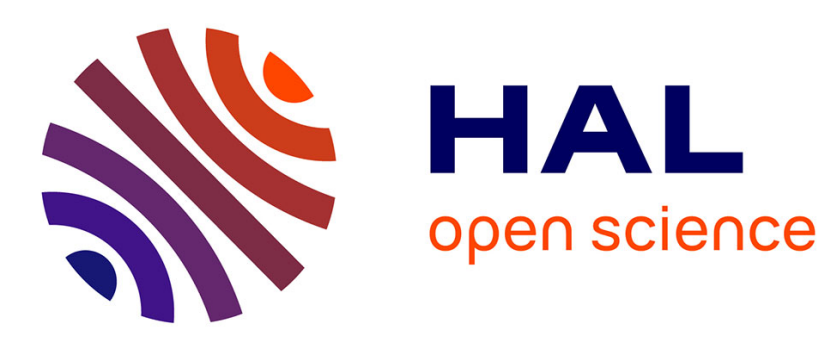

\title{
Monetary Policy and Value Judgments : Did we forget Myrdal's legacy?
}

Nicolas Barbaroux, Michel Bellet

\section{To cite this version:}

Nicolas Barbaroux, Michel Bellet. Monetary Policy and Value Judgments : Did we forget Myrdal's legacy?. 2014. halshs-00952009

\section{HAL Id: halshs-00952009 \\ https://shs.hal.science/halshs-00952009}

Preprint submitted on 26 Feb 2014

HAL is a multi-disciplinary open access archive for the deposit and dissemination of scientific research documents, whether they are published or not. The documents may come from teaching and research institutions in France or abroad, or from public or private research centers.
L'archive ouverte pluridisciplinaire HAL, est destinée au dépôt et à la diffusion de documents scientifiques de niveau recherche, publiés ou non, émanant des établissements d'enseignement et de recherche français ou étrangers, des laboratoires publics ou privés. 


\section{WP 1408 \\ Monetary Policy and Value Judgments: Did we forget Myrdal's legacy?}

Nicolas Barbaroux, Michel Bellet 


\section{GATE Groupe d'Analyse et de Théorie Économique Lyon-St Étienne}

93, chemin des Mouilles 69130 Ecully - France

Tel. +33 (0)4 72866060

Fax $+33(0) 472866090$

6, rue Basse des Rives 42023 Saint-Etienne cedex 02 - France

Tel. +33(0)4 77421960

Fax. +33 (0)4 77421950

Messagerie électronique / Email : gate@gate.cnrs.fr

Téléchargement / Download : http://www.gate.cnrs.fr - Publications / Working Papers 


\title{
Monetary Policy and Value Judgments: Did we forget Myrdal's legacy?*
}

\author{
Nicolas Barbaroux ${ }^{\dagger}$ and Michel Bellet ${ }^{\ddagger}$
}

October 2013

\begin{abstract}
Myrdal's works are usually analysed with a dual and separated point of view: on the one hand the methodological papers concerning the value problem and based on a strong non neutrality thesis ; on the other part the theoretical analysis concerning monetary theory and policy, with a Wicksellian filiation. In fact both the dimensions are strongly connected by a common way: the application of the Hägerström's Swedish guillotine between is and ought, but also the construction of a bridge between economic science and political views on social engineering and economic policy. Myrdal wants to address this problem: how economic science can become politically relevant? This paper analyses two stages of that unique project: the proposition of a "technology of economics" (1930), and the selection process for "a norm for monetary policy" (1939). It shows that Myrdal distorts an initial end and means scheme by proposing some intermediary concepts between positive and normative fields. From a theoretical and statistical framework and an explicit value judgment these concepts enable to elaborate an iterative tree of selection of a specific monetary policy. If the Myrdal's project encounters difficulties in conciliating a non-cognitivist thesis with economic prescriptions and in proposing a tractable method, it remains an important benchmark for the analysis of the links between positive and normative views concerning monetary policy.
\end{abstract}

JEL classification: B20, E52, B40

${ }^{*}$ A first version of this paper was presented to the 44th Annual UK History of Economic Thought Conference, Keele University, 3-5 September 2012 ; and to AFSE 62sd Conference, 25 May 2013, Aixen-Provence.We thank Roger E. Backhouse, Michel de Vroey, Mathias Klaes, Philippe Mongin for their comments during the session. The usual caveat holds. This text remains provisional.

${ }^{\dagger}$ Associate Professor in Economics, University of Lyon, Lyon, F-69007, France ; CNRS, GATE Lyon Saint-Etienne, Ecully, F-69130, France. Universit Jean Monnet, Saint-Etienne, F-42000, France. Nicolas.Barbaroux@univ-st-etienne.fr

${ }^{\ddagger}$ Professor in Economics, University of Lyon, Lyon, F-69007, France ; CNRS, GATE Lyon Saint-Etienne, Ecully, F-69130, France. Universit Jean Monnet, Saint-Etienne, F-42000, France. michel.bellet@univ-stetienne.fr 
Keywords: value judgment, monetary policy, positive analysis, normative analysis. 


\section{Introduction}

Monetary policy history seems to be the history of monetary policy rule ła Taylor (Asso, Leeson, 2012). However, little has been written on value judgment embodied in whatever monetary policymaking. Woodford's Neo-Wicksellian (2003) monetary policy seems explicitly value founded when it defines a targeting zero inflation rate, a nil output gap: thus monetary policy becomes optimal. But this optimality remains poorly justified and welfare concepts are sidelined. ${ }^{1}$

Gunnar Myrdal's contributions enable us to fill in the gap: Myrdal is interested in monetary policymaking (Monetary Equilibrium, 1939), while taking into account value judgment (The Political Element in the Development of Economic Theory 1930, and other later works). In the history of economic thought, concerning the specific issue of "valuejudgment in economics, Myrdal is traditionally presented as the archetypal of "strong or strict non-neutrality" thesis. Indeed, in his most famous stances (notably in 1958 documents), Myrdal seems to claim that social scientists (and not exclusively economists) cannot but make value judgment in their work. In both theoretical and practical matters, they are simply guided by their values. ${ }^{2}$ This interpretation of Myrdal's thesis makes it the strict opposite of Robbins' famous one (1932). ${ }^{3}$ In the same time, Myrdals specific and permanent stance regarding the critical importance of the "practical question" with policy recommendations for economic policies (and especially for monetary policy) is notable. Within a large Swedish filiation (mainly Wicksell), he was a very important member of the so-called Stockholm School (Jonung 1993, Bellet, Palermo, Zouache, 2004); his contribution on monetary theory and policies in the 1930s is appreciated in history of political economy and in monetary macroeconomics.

But curiously, in the scholars studies, the two lines of analysis (value judgment and monetary policy) are isolated. When we read many comments on value judgment concerning Myrdal, we find nothing concerning his works in the monetary field, and conversely. We can also note that Myrdal's initial approach on value judgment (during the period 1914-the mid 30) is usually unaddressed while this position, when briefly evoked by commentators, seems the exact opposite of the one traditionally referred to. Young Myrdal advocated then an (not extreme) value-neutrality position for the positive science faced to value judgments. So, how to understand such a radical change in Myrdal's views, and why only mentioning the unique so-called 'institutionalist Myrdal of the second period?

We argue that the usual interpretation of Myrdal's views when it comes to the separa-

\footnotetext{
${ }^{1}$ See Atkinson: 'Welfare economics has largely disappeared from sight, a disappearance that is strange in the sense that economists have not ceased to make welfare statements". (2009: 793). He mentions very briefly the policy makers loss function, that is very used for monetary policy. That function penalizes output, inflation and interest rate variability, with different weights.

${ }^{2}$ See for instance the Mongin's important text (2006: 4-5 and 15-17), or D.W. Hands, 2012.

${ }^{3}$ Robbins' thesis (1932) itself would deserve a specific discussion and disputes: see his 1961 article in 1963 Economics and Politics; see also Cowell F. and Witztum A. (ed., 2007). Here we refer to a well-known and basic interpretation (strict neutrality thesis).
} 
tion between positive and normative economics (the divide between "is" and "ought" or the famous Hume's guillotine), influenced by Robbins (1932), does not sufficiently addressed what really preoccupied Myrdal. Starting from Myrdal's actual questionings, we wish to open a research agenda on the history of economic thought regarding the linkages between value judgments and economic policies. ${ }^{4}$ For many reasons, Myrdal is a major contributor to this history: following the Swedish tradition (in particular Wicksell), he obsessively seeks to reconcile pure science with policy recommendations; he wants to preserve the specific status of economic policy and more generally social engineering ${ }^{5}$, keeping a rigorous tie with economic science and not a simple and strict dichotomy; his thinking is clearly policy-oriented especially concerning monetary issues. Considering that economic policy implies steps of evaluation and economic prescriptions (Mongin 2006, Baujard 2012), the presence of value judgments is reinforced (thought not exclusive).

Therefore the focus of the paper is to cope with Myrdals contribution regarding the link between the judgment of values and economic policymaking. In this article, we will put the stress on monetary policy due to the fact that following the current financial crisis it is in the front stage of the macro agenda. Moreover, the Swedish economists were mainly involved in the field of monetary policymaking owing to the weight this debate held in their time (interwar period and the strong debate on monetary stabilization policies). First we introduce the strict neutrality approach of young Myrdal, which presents itself as a permanent critique of Wicksell, but keeping his major questioning: how can the economist intervene as a scientist in the fields of economic and social policies? From an initial schema ends and means originating in Wicksells paper $(1904)^{6}$, the major solution Myrdal (1930) propounds is recourse to a "technology of economics", linking economics and politics, and making policy recommendations possible. Second, we show how the major work of economic theory written by Myrdal, Monetary Equilibrium (1939), is a prolonging of this proposal. Myrdal proposes to improve the relationship between monetary theory and monetary policy from the notion of a "norm of monetary equilibrium", with practical applications, which is a way to tackle the question of value judgments and to develop his notion of "technology of economics. So we defend the consistency (with some variations) of

\footnotetext{
${ }^{4}$ Concerning a research program on value judgment, see Backhouse (2005), Mongin (2006), Baujard (2012).

${ }^{5}$ This Myrdallian expression has a deeper meaning than "economic policy: it expresses the possibility of scientific solutions concerning all problems of society, in a spirit that for the author would mirror the Swedish social-democratic project of the 1930s (Myrdal joined the Social-Democratic Labour Party in 1931).

${ }^{6}$ The ends-means scheme is the following: "ends" (or purpose) refer to a desirable situation (the "ought") and imply value judgments (in the broad sense). "Means" refer to various courses of action to attain the end (scientific courses for example), to describe the "is"). Means are supposed value-free. Myrdal (1931-1933) introduces a third category, incidental effects or "by-effects" (desired or not). Lindahl (1924/1930) uses the diptych aims [mål] and means [medel], but "medel" is sometimes translated by "methods" and the diptych disappears in 1939 English version. Robbins (1932, title of part II) also uses the ends-means framework and chooses to ignore the ends by focusing on means (cost minimisation, when there is scarcity).
} 
the Myrdal's program, now obscured by some too univocal interpretation concerning the normative issues (Myrdalian "institutionalism", 1958) or concerning the theoretical and practical analysis (Myrdal the monetary equilibrium theorist and the defender of active monetary policies, 1939).

\section{Myrdal (1930) and "the technology of economics": how to strictly distinguish value-judgment from sci- ence, but also how to bridge them in order to legit- imate economic policy and social engineering.}

When it comes to value judgments and economics, there is a general tendency to only remember a few works by Myrdal, typically the ones gathered in the 1958 volume $^{7}$ and the major piece of 1944, Asian Drama. Myrdal is thus considered as the author who advocated the non-neutrality of the economic discipline, a thesis associating him with institutionalism. More careful analyses, exemplified by Mongin (2006), rank Myrdal among the tenants of a "strong non-neutrality" thesis, without putting into question the traditional interpretation of Myrdal's work as being opposed to the other symbolic figure of the opposite thesis Lionel Robbins. To some extent, the opinion of Myrdal's economic colleague, Lundberg, confirms this point of view but he also values the first (young) Myrdal, often forgotten, presenting it as a value-neutral methodology and depreciating the second more "institutionalist" Myrdal:

"Myrdal has returned to the valuation problems in economics, and sadly enough clear-cut and extremely stimulating exposition and refreshing conclusions of 1930 have disappeared and have been substituted by rather muddled thoughts on value relativity problems entering at every stage of research" (Lundberg, 1974: 478).

It is surprising that the initial stance of Myrdal regarding value judgments, particularly over the period 1927-1930, has not been seriously studied. This original position is sometimes attached to the influence of Swedish philosopher Hägerström (1868-1939) with a few mentions of his name ${ }^{8}$, but is never discussed as such $^{9}$. Of course, this lack of interest

\footnotetext{
${ }^{7}$ Often it is overlooked that the 1958 collection is not uniform: ten out eleven contributions, written during a 1944-1957 period, are connected with a "strong non neutrality" thesis. But one is the translation of a Swedish article written in 1931 (from its German version, 1933). This paper continues the 1930 book, with a "strong neutrality" thesis, looking for solutions, and distorting the end-means scheme. Schumpeter did not accept the paper for publication in Archiv for Sozialwisenschaft and Sozialpolitik, with Myrdal's frustration (1958: 255). To our opinion, this article is the most fully developed in Myrdal's works on the topic of values.

${ }^{8}$ For instance Barber (2008), a recent biographer of Myrdal, only mentions once the name of Hägerström.

${ }^{9}$ Cherrier (2009: 35-38), looking at numerous archives concerning Myrdal, attached some importance to it, but the only real exception is Strang $(2007,2010)$, even if this scholar restricts the Hägerström's
} 
may be a consequence of the very limited and quick remarks of Myrdal himself on that initial stance ${ }^{10}$, which may let people, think it was only a very precarious frame of thought, weakly designed and ultimately unclear. However, in relation to our own research focus, i.e. economic policy, this interpretation of the first Myrdal is neither sufficient, nor tenable.

The references to the Uppsala School philosopher A. Hägerström and his thesis on value judgments is in fact symptomatic in various ways of the first Myrdal (1927-1939), even if the 1930 piece known in its English version as The Political Element in the Development of Economic Theory (from a series of lectures delivered in April-May 1928 under the title "The concepts of "value" and "utility" in economic theory"11) is its most significant expression. Myrdal (1930) will therefore be used as a reference in what follows.

The Hägerströmian value theory $(1911)^{12}$ can be presented as follows:

- A "value nihilistic theory": moral judgments are void of any cognitive content. They cannot be true or false, in the sense that they are not a judgment on reality. They are cognitively meaningless (non-cognitivistic theory); the value is nothing to do with the quality of objects because this notion has no meaning without an emotional experience which is introspective. Values are not reality. Therefore the value judgments are pseudojudgements because they consider values to belong to reality ${ }^{13}$.

influence to some aspects of the value theory, and does not integrate Myrdal's monetary theory works (especially 1939).

${ }^{10}$ As acknowledged later on by Myrdal himself (postscript in 1958: 250), who refers to this influence "in a general and sometimes vague way". This text by Myrdal could also have been influenced by an economic reference mentioned twice by Hägerström (1916): a document (1902) by the historian and jurist Stjernberg (1873-1943) that criticizes circular reasoning in economics (see Myrdal and the denunciation of "logical circles", "circular definition", "circular reasoning", 1930: 14, 16, 20...). Moreover the 1930s book wrote: "Hägeström's main thesis is the central point of view of the present critical analysis of economic theory." (1930 :13). See also 1958 postscript: 250-251. For us, Myrdal seriously read Hägerström's works and has been deeply influenced by them.

${ }^{11}$ The initial article in Swedish, Vetensskap och politik i nationalekonomien (1930), was translated in German in 1932 and from German to English not before 1955. See Strang (2007) for a translation update on the original text in Swedish.

${ }^{12}$ Joergensen (ed. 1970), in a famous volume of articles regarding logical empirics, Foundations of the Unity of the Science, highlights the particular role of the Uppsala School, founded in the years 1910 by A. Hgerstrm and A. Phalèn (1864-1931). Anticipating more famous authors from the School of Vienna (Carnap...) and what will be called logical positivism, Hgerstrm questions the very existence of a metaphysical science. Metaphysics proposals (in philosophy, but also in Law, or regarding scientific discourse on moral) cannot be demonstrated and tells us nothing on reality. However, contrary to the School of Vienna, Hgerstrm does not refer explicitly to the role of experience and feelings as the foundations of sensibility: experience can only be the source of knowledge because it embodies logical relationships (identity and non-contradiction principles). Hägerström is therefore neither an empiricist, nor a sensualist. He had some contacts with the Vienna Circle (instituted in 1923). See Strang (2010) for a detailed analysis of Hägerström's thought and its context. See also a biography and an analysis by Mindus (2009, especially chap. 6), Petersson's Swedish works (except 2011 in English) and the recent Centennial Symposium "Axel Hägerström and Modern Social Thought", 23-24 Sept. 2011 (unpublished).

${ }^{13}$ However, as indicates Petersson (2011), Hägerström modified his theory after 1912, making a distinction between what he called primary and secondary valuations. He restricted his emotive theory to primary valuations only, and applied an error theory to secondary ones. 
- An emotional theory: moral judgments (as specific value judgments) have to be interpreted as emotive outbursts (ethical emotivism ${ }^{14}$ );

- A theory about morality, not a theory of morality: Theory can only explore actual values praised by individuals or groups, but can never analyze or prove absolute values. Morality is a subjective mode of thinking that can be object of science (with historical, psychological, anthropological explanations) but definitely cannot be a ground for it. "It is clear that knowledge of actual valuations is by no means knowledge of value". (1916-1939: 90)

But other elements of Hägerström's philosophy, connected with the value theory are sometimes forgotten although for us they have a role to play in Myrdal's attempt.

- A concept of norm: a norm as a moral idea of duty, different from a moral idea of value, remains a subjectivist mode of the thought. Norm does not exist, but only our idea of norm exists, more and less consistent and operating. Norms are neither true nor false because they necessarily integrate an emotive component that is neither true nor false. However they have a strength and validity which are only connected with a psychological and sociological reality (a general conviction that gives them a power of exhortation). When they are valid and recognized norms are neither the result of the will of the State nor the result of the General Will: they are an outcome of groups exercizing de facto power in society ${ }^{15}$, but in the same time their power is recognized by all including theses groups.

- A criticism of the theory of rights (or duties) as social superstition in which the notion of interest plays a major role. The non-cognitivist critical area of value judgments also concerns in a specific form the "rights and the "duties. Especially the idea of "rights (like the property right) derives from an old magic vision and is developing in a form more complex than the moral values. That idea is an arrangement of diverse logical and psychological elements: ideas about values (emotions), interests, beliefs ${ }^{16}$. For example, the private property rights are said to stand "an inextricable connection to interest" and to be a "superstructure of our interests" ${ }^{17}$ (a system of interest among social classes or groups). The definition of interest is broad: interests are economic, but also they are "general human aspirations" or "ambition" (in a Smithian definition). Interests thus defined required as emotions a non-cognitivist approach (the true or the false criterion is not possible).

In an environment characterized by a struggle against liberalism ${ }^{18}$ (but also, one should not forget, against Marxist socialism), Myrdal's work, sometimes introduced as a critical

\footnotetext{
${ }^{14}$ Concerning a brief historical survey of emotivism of which Hägerström was one of the pioneers, see Satris (1982) or Tsinorema (2008).

${ }^{15}$ The John Austins influence is manifest here with a concept of law de facto laid down by some groups of individuals (legal positivism).

${ }^{16}$ This presentation is in line with Mindus (2009: 190-193). The belief status seriously complicates the interpretation of Hägerström's non-cognitivism (with consequences on Myrdalian views).

${ }^{17}$ Mindus mentions that Hägerström directly refers to Marxist conception of rights. (2009: 191n.116, and 6.4.1 and 6.4.2).

${ }^{18}$ Concerning the reading from Myrdal of Keynes The End of Laissez-faire (1926), see again Cherrier (2009) and Strang (2007).
} 
history of political economy, questions the frontier between economic science and politics and more generally between science and normative practice (the value problem ${ }^{19}$ ), and to this end applies Hägerström's philosophy. For Myrdal, economic thought since Stuart Mill, Senior or Cairnes has for the most part clearly delimited the field of competence of economic theory, but did not respect the frontier in providing a passage from the notion of scientific "law" to the notion of "norm per se" (here understood as "desirable economic action"). For instance, authors would easily move from a definition of free competition as scientific relations associated to specific hypotheses to a definition in terms of "maximum of satisfaction", which could be used to justify a political choice. From Physiocracy to Neoclassical Marginalism, along with the Classics, Myrdal examines three notions that symbolize this blurred frontier: Value, Liberty and Social Welfare. At the root of the "natural law" and Utilitarianism doctrines (and not the theories) these notions explained all over history the significant rise in economics of "norms per se" and value judgments ${ }^{20}$ similar to an economic theology.

Myrdal (1930) thus identifies two criticisms. First, political doctrines do not fulfill any scientific criteria: they do not respect logical coherence (understood as a relation between the hypotheses or priors and the conclusions) proper to any theory; the divide between means and ends do not lead to any system of causal relations; value judgments and "norms per se" cannot be objectively assessed and attempting to build scientific foundations from them leads to a "false analogy between science and emotions (Hägerström). For Myrdal, political phenomena have a particular relationship with practical questions. One part of these phenomena can be treated by economics on an objective and scientific basis ${ }^{21}$ (without value judgments), meaning the definition of the situation and of the consequences of possible actions in response to the situation; another part relates to hypothesis that are not available in science, namely the choice of desirable effects (valuation). The logical relation between normative hypotheses (notions of "natural law" for instance) and practical conclusions does not exist in the scientific field. Secondly, it is necessary to separate the two fields. Myrdal (1930), following other young neo-Wicksellians who will form the School

\footnotetext{
${ }^{19}$ Myrdal (1930) often uses the word "valuations" and less often the term "value judgments" in the same meaning. In that book, valuations or value judgements are limited to political ones. Starting from 1944, Myrdal will consider separately valuations and beliefs as two distinctive ways of accessing reality (beliefs: ideas about how reality is or was ; a belief can be judged true or false ; valuations: ideas about how it ought to be, or ought to have been ; a valuation cannot be judged by criterium of the science). Therefore in his "strict non neutrality" period Myrdal will maintain in a different form his reference to Hägerströmian emotivist theory. He will only introduce a rational part (with belief notion) in what before was understood as entirely non logical: "In their opinions people express both their beliefs and their valuations" (1944 or 1958, chap.5, 71, or 1970, chap.VI). The link between valuation and belief is the following: "when the valuations are conflicting, as they normally are, beliefs serve the function of bridging illogicalities" (1958: 76). Note that "belief" notion is also a Hägerströmian notion, but Myrdal does not introduce it before 1944. See supra on this point.

20 "Norm per se" is a systematization of value judgment (often implicit ends) by pseudo-logical means. As we saw, that notion originates from Hägerström. Later (1939), Myrdal will use a more positive notion of norm, but through Hägerström's works.

21 "The politician may reasonably expect the economist to explain the actual situation and state the effects of different possible modes of action in relation to the same initial situation" (1930: 2).
} 
of Stockholm, develops an "immanent critique" of Wicksell on the basis of Wicksells own normative criterion. With Myrdal (1930), the relation between means and ends becomes a strict problem of scientific methodology: it is a logical (and not moral) relation that must fulfill the requirement of internal validity and coherence (causal relation between hypotheses and results). Myrdal prolongs here the Wicksellian tradition (1904) against the German Historical School regarding the importance of theory and the role of practice, norms and politics: the tradition of managing monetary interest rates, particularly relevant for our article, but also the tradition of fiscal policy analysis in Swedish political economy. However, he is more rigorous than his master on the separation between the two dimensions, denouncing as Hägerström the irruption of metaphysics (a social ideal) within sensitive statements. Rather than Wicksell's notion of the "greatest happiness for society" (included the proletariat) ${ }^{22}$, Myrdal refers to an explicit norm of progressive elimination of social groups logic of conflict unjustified by the non-scientific principle of harmony. Economics could apply its means to such a norm but it remains an exceptional case ${ }^{23}$ : conflict between groups prevails. Myrdal describes his distrust about "communistic fictions" (1930: 145, 194) as common interest, welfare which have no clear foundations. He contests the interpersonal comparisons of utility, the shadow distributional income effects in the welfare purposes (owing to the fact that growth favored specific groups in the expense of others). In this way, implicit value judgments play a role in the prescriptions (indifference toward the consequences of the redistribution of income). In the same way, Myrdal criticizes the Swedish theory of public finance and fiscal policy (Wicksell and Lindahl) which also seeks a notion of "justice". Beyond strict references, the use of Hägerströmian theses is thus clearly noticeable $^{24}$. It leads to a stance on value judgment more robust than the one defended by Weber. The latter was respected by Myrdal but criticized for his lack of knowledge of economic theories and his "hesitation on the matter of value judgment". Myrdal blamed him for suggesting these judgments could result from a logical (scientific) approach: "the desire to think of moral evaluations as if they were logically coherent is a legacy from the days of the metaphysical systems" (1930: 203).

\footnotetext{
22 "The goal of economic activity must be the greatest possible social prosperity, individually and collectively". Wicksell considers once the good concept of society has been defined, economic science has all the tools to treat this question. Myrdal (1930:XV) criticizes the following passage from the Lectures (Wicksell, 1901, t.1): "The very concept of political economy therefore, or the existence of a science with such a name, implies, strictly speaking, a thoroughly revolutionary program".

${ }^{23}$ Which may refer to the scientist illusion of social engineering in the $30 \mathrm{~s}$, but also to the specific issues and periods : "For monetary policy, the assumption of a harmony of interests is, perhaps, more often realistic than for other spheres. Yet, even here there have been disputes over the "correct" meaning of such terms as "value of money", "inflation", "natural rate of interest", and "equilibrium in the capital market" (1930, 192-193).

${ }^{24}$ Myrdal usually limits himself to the contestation of the objective feature of "norms" that can never be justified through the use of scientific principles. In that sense, he follows Hägerström who underlines for instance the use of "magical devices" in Roman Law. Myrdal, expecting a few remarks on the purpose of words and metaphorical figures (1930: 5 or 19-20), does however not mention the role of grammatical forms and language as the only tool of legal objectivity.
} 
Once all the criticisms have been exhausted, what is the solution for Myrdal? Myrdal then develops his more central points: the question of the "practice", along with the political economy question of his own program of social engineering. His radical demarcation between science and value judgments only serves to justify the existence of a bridge. The permanent problem of Myrdal is to have economic science being used for practical purposes in the context of the 1920s. This problem explains the chapter 8 ("the role of economics in politics") of his 1930s book, the central contribution we believe. Myrdal position is organized around two arguments:

- Economic policy necessarily assumes a confrontation of its concepts with value judgments, which themselves refers to diverging interests. Theory may pretend to come up with general recommendations (a real norm) only when harmony of interests is insured. The existence of a monetary policy explicitly assumes a clear definition of this norm.

- One should however not confound a situation where harmony can be observed with a scientific principle of universal scope. Conflicts of interest can never be solved scientifically, they can only be acknowledged by the scientist. The work of the economist to "rebuild the social field of interests" ${ }^{25}$, meaning the identification of cases where interests differ or converge between social groups, is objective as it expresses explicitly value judgment corresponding to the interests of these respective social groups. Every philosophy of economics that supposes the harmony of a "human nature" (utilitarianism) or a "social interest" (Historical School, Marx) hides the conflicts of interests and should not be trusted for this reason.

So Myrdal then advocates the construction of what he calls a "technology of economics" or "the study of the politics of economics", which is a scientific theory on the way politics can serve concrete interests (1930: 196). The purpose is to complement abstract economic theory with an applied economic technology and institutional dimensions. Revealing economic interests (with the corresponding social groups) ${ }^{26}$ requires considering the "institutional set-up" and the way it can be modified. Under this expression, the author means "the legal order" and "the customs, habits and conventions, which are sanctioned, or at least tolerated, by the legal order" (ibid). The "technology of economics" requires to understand the existing institutional background but also its change, to the extent the objective consists in knowing how the modification of various interests (through the establishment of taxes, legal reforms) can allocate more power to some groups and allow for a progressive transformation of the social order (Myrdal referred to the establishment of an "political democracy"27). Myrdal refuses the term "system" to qualify this institutional arrangement as it corresponds to a generalization that does not consider the internal dif-

\footnotetext{
25 "It should be one of the main tasks of applied economics to examine and to unravel the complex interplay of interests, as they sometimes converge, sometimes conflict... "(1930: 193 and following).

${ }^{26}$ The Hägerström's influence is identifiable (interests behind the norm), and is not exclusive to the emotion theory. As has been seen this reference to (often divergent) interests is connected with Marx: Hägerström wrote a specific text concerning this author in 1933 (even if he criticised teleological elements in Marxian doctrine). We note that the reference to Hägerström prohibits a conception of interests as objective and materialist data.

${ }^{27}$ See 1930: 199.
} 
ferences of power (and rules) and the possibility of gradual variation. For this reason, he criticizes expressions such as "system of private ownership" or "communism", which all suggest the existence of various systems over which a logical choice may arise while on that regard, only history matters.

The "technology of economics" must therefore identify precisely enough the power repartition between social groups and "should reflect possible strategies as in a "war game" "(1930: 198): its purpose is to derive possible institutional changes from explicit value judgments, always in relation to the interests of groups, so non-universal. A last difficulty appears when, according to Myrdal, this technology does not address purely economic interests but also "social attitudes, "ideals much larger, and attached to moral sentiment and emotional dispositions of individuals and groups. Political aspirations cannot be strictly identified with economic interests. Myrdal advocates a "social psychology" (or a "modern psychology orientated sociology") allowing to identify the relevant attitudes, indispensable to his branch of economic technology: he anticipates its future conversion to a scholarly extension (1944), but at that time, he wants to use the technology of economics for giving economics a decisive role in politics (and so in economic policy). One should keep in mind that for Myrdal, the analysis of attitudes or ideals cannot identify logical relations between attitudes in various situations: "clearly, there are such connections, but they are psychological, not logical" (1930: 204). Myrdal questions Weber's emphasis (1922) on the consistency of the value structures elaborated by means of axiological value analysis (with a logical tracing back of concrete values to ultimate value axioms ${ }^{28}$ ). Hägerström's influence is very clear concerning this point. To derive according a single hierarchy all valuations from a supreme norm is a false process, and a metaphysics of rationalization. However the problems we face are twofold. Firstly what is the status of that technology? Is it a real science? Myrdal is hesitating on this issue but he uses the expression "psychological science, and sometimes the expression "an another type of science ${ }^{29}$, not yet entirely elaborated. Hägerström's thesis was a study on values can usefully focus on the emergence and the evolution of values (in laws or morals), and so unravel our emotions and also our interests without once a scientific point of view being possible (there is no objectivity in values). Myrdal seems to pursue this kind of approach but with the same difficulties ${ }^{30}$. Does Myrdal attempt to apply to political values the theory Hägerström built concerning the rights (that as mentioned cannot be identified to moral ideas and present a part -belief- that can be analysed with true-false criterion)? It is difficult to clear this question

\footnotetext{
${ }^{28}$ See Myrdal, 1930: 202-204 and Myrdal, 1931-1933: 215-219. Concerning Weber's axiological value analysis, see Bruun (2007).

29 "Perhaps this is ultimately not science in the strict science. It cannot be reduced precisely to true and false". (1931-1933: 229)

${ }^{30}$ As previously mentioned, in his intricate theory of rights, Hägerström introduces a notion of "belief" which makes the behavior intelligible because beliefs can be judged by scientific criterium (see Mindus chap. 6). We noted infra that Myrdal does not use this notion before 1944, but then he uses it for this precise goal: beliefs "offers us a clue for analysing scientifically the complexes of struggling valuations that exist in the minds of people" (1958: 84).
} 
from 1930 and 1931-1933 works ${ }^{31}$. This point is very important because the technology of economics constitutes the coping stone of practical economics between positive and normative analysis, and modifies the ends-means framework. Secondly the large diversity and relativity of value premises (which depend themselves on the different interests of social groups) lead to difficulties. In fact the delimitation of the value premises is the result of the role of value judgments not only in ends, but in ends-means-by-effects. Contrary to a superficial definition of the value premise notion, Myrdal does not suggest selecting some value judgments into a list, then starting a theoretical and empirical concerning means. To Myrdal:

"Ends cease to be the sole value premises and can no longer be used as simple categories for classifying alternatives courses of action [i.e. means]. Every combination of end, means, and by-effects, i.e. every alternative sequence itself, thus becomes a value premise and a category of classification". (1931-1933: 213)

Economists have to examine and compare a large range of sequences, hence an analytical and practical complexity (except the rare case of harmony of interests). In order to reduce this field, in 1930 Myrdal hesitates concerning a selection of "present and concrete values (in 1944 book about the Negro problem, he will not hesitate to select a group of valuations ("American creed") and to interpret them as social facts like five other variables).

Myrdal thus lays out:

- An explicit introduction of valuations (or value judgments), as empirical facts;

- A link between valuations and interests (economic interest, but also social attitudes, with anticipations). This link is not logical, but socio-psychological;

- A relativism of values, except in the rare case of harmony of interests. The way value judgments and interests are aggregated within a group or between groups is not specified however ${ }^{32}$. Note that this relativism affects all the framework ends-means, and not exclusively the ends. Moreover, Myrdal sometime evokes an initial choice of "concrete, present value premises that limits a global relativism.

- A call for a future science of interests (psychological, sociological, institutional) that would complement economics so as to make economics practical. The future science is not

\footnotetext{
${ }^{31}$ We could try to solve this impasse by invoking a Swedish solution "à la Wicksell" (1904): the technology of economics is like history for Wicksell an "auxiliary science" for economics. But this solution is trivial and not particularly exciting to the extent that the Hägerströmian (and Myrdalian) non-cognitivist thesis disappears. Myrdal sometimes seems prepared to select some values from the technology of economics: this would provide "actual values" that could be inserted in a scientific interpretation as empirical facts. But the consistency with the non-cognitivist approach may not always preserved.

${ }^{32}$ The expression "political democracy" remains no clearly defined. As we saw supra, Myrdal did not believe either interpersonal comparisons of utility, or a social summation operator (1930: chap. 2 and 4). Conflicts between asymmetric power groups (with "possible strategies in a war game") seems to be the reference framework, even if the possibilities of coalition games are not developed. A State voluntarism, connected with economic planning and social engineering often seems to outweigh. In some papers we do not mention here, Myrdal and his wife Alva seems to be seduced by the opinion poll apparatus (Gallup) as a modern referendum.
} 
a logical reasoning ; it highlights emotive dispositions of an individual or a group to face to actual or potential situations. For practical use, value premises have to be prepared on the basis of "a socio-psychological study of attitudes, behavior, opinions, ideology" (1931, $230)$.

- Means are not value-free, because value-judgments imply alternative sequences connected with couple ends and means (or even triplet end, means and by-effects), each one corresponding to some special interest.

- Economics can develop prescriptions even if there is a bridge between economics and politics, but connected with science by comparing alternative sequences connected with different "value-premises (may be selected from "actual values recognized as empirical data using a technology of economics)

- politics is being left irreducible ${ }^{33}$. The technology of economics is only an intermediate level between economics (science) and political values. With this apparatus, Myrdal's thesis could be qualified as a "weak neutrality" thesis, because an intermediate zone, with specific tools,can be elaborated to connect positive and normative economics.

\section{Myrdal (1939) and Monetary equilibrium: from the "technology of economics" to "monetary equi- librium as a norm".}

We claim that Myrdal's attempt to first separate and then bridge science (economics) and politics, legitimating prescriptions and "practical economics", follows the same path after 1930. However, in academic discussions, when Myrdal's work is accounted for over this period and in particular when it comes to monetary policy and equilibrium (the so-called Stockholm School), the value judgment approach disappears ${ }^{34}$. Palander (1941), Shackle (1967, chap.10), Hansson (1982), Myhrman (1991), Trautwein (2005, 2011), Siven (2006

\footnotetext{
${ }^{33}$ It is a clear difference from Robbins' position. To Robbins, as much as possible economics needs to be clear of politics, with: "a system so unequivocal in its prescriptions regarding the conduct of what was conceived as economic policy that, within this sphere, its logic, if not its power to coerce unreasoning politicians, might be regarded as all-compelling." (1963: 12). Wicksell, within his more flexible view (because he admits an intermediary role of a concept of "society") also thinks that with an extended synthesis of fundamental economic concepts (and not the "economic dilettantism" of the Socialism of the Chair or Bastiat's liberalism), disagreements appeared to be resolved. Political conflicts between individualism and socialism can be decided with scientific tools ; therefore, practical economic problems can be connected with a very open-minded notion of welfare of the society (1901: 64). Myrdal's framework is more sophisticated and he concludes: "The paradox lies in the fact that practical political economy can become objective only through ascertaining the political will without disguise, in all its important manifestations, and through fitting these directly into scientific analysis as its alternative, simultaneously present, value premises." (1931-33: 230)

${ }^{34}$ Curiously, Strang (2007) does not address Myrdal (1939) in his precise and pertinent work on the evolutions of the author. However, it provides precious indications on intermediary elements from 1931, 1932 and 1935: Myrdal partially departs from the Hägerströmian position on numerous occasions (introducing a distinction between naive value and critical value; discussing the selection of the value priors, developing optimistic view concerning the capacity of the Social-Democratic Party to manage a new harmony of
} 
part III) never mention this topic in their comments on Myrdal's monetary views. A unique exception is Laidler (1999), but without mention for 1930 book $^{35}$.

This approach is decisive however as the work of 1939, Monetary Equilibrium (initially coming from a work in Swedish from 1932 but published in 1931, and then from a German version of 1933), is the one which exemplifies the most the kind of mediations thought about by Myrdal between monetary theory and monetary policy, so the treatment of value judgments. For what follows, we thus refer to Myrdal (1939).

The content of the economic analysis of Myrdal should be recalled first. Following early discussions within the Stockholm School, Myrdal decides to improve the Wicksellian critique of the cumulative process, which was founded on a gap between the "natural" interest rate and the "monetary" interest rate. He "includes anticipations in the monetary system" 36 . The ex ante versus ex post analysis provides a temporal framework for anticipations, with a new refinement in the notion of equilibrium. Anticipations constitute the roots of dynamic analysis, as disequilibrium is made possible: ex ante anticipations may not correspond to ex post results. The notion of equilibrium is maintained, but it now depends on existing conditions at a given period, when ex ante amounts equal ex post results. The slightest gap between these two quantities lead to a revision of anticipations, and a cumulative process that renders impossible a return to the initial situation. The equilibrium is "unstable" (and not long-term), and the monetary equilibrium is "the opposite of a trend" 37 . In the years 1933-39, the analysis of such a process and its temporal dimension, are grounded on the immanent critique of the Wicksellian cumulative process. Myrdal reinterprets the initial framework of Wicksell, organized around the gap between natural and monetary interest rate. He keeps alive the reference to the structure of production, with the role of roundabout methods of production, but alters the definition of natural rate and the conditions of equilibrium. The Wicksellian tradition remains strong as it has the cumulative process intervening on prices only, in a context of theoretical integration between monetary theory, theory of interest and capital and thus the whole central price theory. Moreover, that tradition leads to a practical recommendation: a "regulation" of the monetary interest rate by the central banks, in order to prevent the cumulative $\operatorname{process}^{38}$ (Jonung 1979).

interests with social engineering and planning). In some of these departures, Myrdal seems to come close to the "weak neutrality thesis" (Mongin 2006) of the kind developed by Samuelson or Robinson (a list of some explicit and contained value judgments) even if his fundamental position is less simple (see infra 1931-33's paper in 1958).

${ }^{35}$ see chap.III, 67

${ }^{36}$ Hansson (1982) highlights that this sentence, defining "the main purpose" of the book, having been interlined in the original text, had been added in the German version Hayek to distinguish it from the works of Hayek in 1931 and 1933.

${ }^{37}$ Generally the modern interpretation of this equilibrium in a non-stationary economy is temporary equilibrium (with differences between Lindahl and Myrdal concerning discrete approximation of a continuous process). We dont precise these points here.

${ }^{38}$ In practical economics, Wicksell recommends to central banks to observe the rise or fall of general level of prices (because the natural rate of interest is difficult to identify), and to fall or raise the money rate of interest. 
Three connected conditions are delimitated and reformulated by Myrdal for monetary equilibrium $^{39}$, which is a reference situation. Here we do not articulate the rationale for reformulating that Wicksellian equilibrium conditions. We only note that theoretical reasons play their role (the dynamic view connected with ex post-ex ante distinction), but also "practical applicability" reasons (1939: 68), especially a possible observation and measurement (available statistics, index necessary to bridge from micro level to macro level) ${ }^{40}$. Therefore we verify that practical issues are not reduced to value issue: a part of practical issues has a positive status. That practical concern is permanent for the Stockholm School, especially with its critical views concerning the non workable aspect of the Wicksellian notion of natural rate of interest. The first condition of the monetary equilibrium says the normal rate of interest (equilibrium rate of interest) equals the marginal physical productivity of the capital $\left(y_{2}\right)$, but with transformed variables: the value of existing real capital $c_{1}$ (which integrates the level of money rate of interest $i$, and credit conditions ${ }^{41}$ ) equals the reproduction cost of existing real capital, $r_{1}$, (which replaces the net return of the planned investments). The second condition relates to the capital market $(I=S)$ but, unlike Wicksell, means equilibrium in the aggregate goods market (not in the loans market): gross real investment $R_{2}$ is equal to the free capital disposal $W$ (i.e saving plus total anticipated value-change of the real capital $)^{42}$. The third condition implies definite relative price relations, which are deduces from the first two conditions : if these conditions are fulfilled, every proportional variation of the general price level leaves unchanged the two previous conditions in real terms. Therefore, the variation rate of the general level of prices over in time, $P \circ$, is equal to a constant. In fact, in an equilibrium situation, if the quantity of money rises proportionally in each period, the general price level varies proportionally. This proportionality implies that the relative prices $\operatorname{Pr}$ are unchanged. Thus, unlike Wicksell, the inflation rate is constant in time and is not nil ${ }^{43}$. Monetary equilibrium is a situation where the money rate of interest $i$ fulfils the connected three conditions $^{44}$. Monetary equilibrium (with its theoretical and statistical positive status) is the foundation for a development of Myrdal's framework on economic policy and value

\footnotetext{
${ }^{39}$ The expression "monetary equilibrium" was coined by Myrdal. Myrdal had followed Lindahl (1930) concerning delimitation of three equilibrium conditions from Wicksell's monetary writings. But Lindahl did not use them in his paper.

${ }^{40}$ The so-called theoretical chapters concerning the concept of monetary equilibrium (chapters III to VI) are full of this type of considerations (for instance, 13 and 16 in chap.V). From this point of view Myrdal is a faithful Wicksell and Cassel's disciple.

${ }^{41}$ The relation between $i$ and $c_{1}$ is the following : $i=e / c_{1}$ with e, net return. $\left(c_{1}-r_{1}\right)$ defines the profit margin, which is zero when equilibrium is realized. The subscript 1 and the subscript 2 respectively refers to existing real capital value and new investment value.

${ }^{42}$ Myrdal often refers to this second condition, "for simplicity" (1939: 163) to develop his reasoning concerning monetary policy (1939, chap. VII and VIII). Schmidt (1995) read that condition as an early version of Tobin's ratio q. In 1998, Tobin recognized that filiation.

${ }^{43}$ That condition is connected with a practical index: because price flexibility is heterogenous, and if sticky prices exist, a weighted index on the most sticky prices will be necessary. As the price of the factors of production dominate among the sticky prices, a practical index considers unaltered prices of these factors.

${ }^{44}$ Respectively : $c_{1}=r_{1} ; R_{2}=W ; P^{\circ}=$ a constant, or $\forall i, j \in$ set of goods, $P i / P j=$ a constant.
} 
judgment.

Regarding this economic analysis, we directly emphasize what really matters to us here. It is precisely the "practical question" that refers to the methodological works of the period 1930-1939. Myrdal always wants to show how economic science can become politically relevant, from an initial Hägerströmian thesis separating science from values. Indeed, in Monetary Equilibrium (1939), with the last three chapters (VII, VIII and IX ${ }^{45}$ ), Myrdal adopts explicitly the conclusions of the last chapter of his 1930 methodological work, with extending notions. To Myrdal, we must distinguish between monetary equilibrium as an instrument within the theory, and monetary equilibrium as practical example of economic policy (with value judgment qualifying the ends), but Myrdal admits the existence of a link between the two. On that regard, chapter VIII ${ }^{46}$ of Myrdal (1939) appears to perfectly echo the methodological positions expressed in chapter 8 of Myrdal (1930). It is thus possible to link more or less significantly monetary equilibrium and monetary policy "norms" (stability of price level, elimination or attenuation of the cycle). The tendency to tie the choice of a normative premise (the smoothing of cycles for Myrdal) to the theoretical analysis of monetary equilibrium is justifiable with a series of mediations. The reasoning adopts three levels as following.

On a first level, the most theoretical, Myrdal introduces a new important notion, "the indifference field" (with a linked concept of "indifference regions"). The monetary rate of interest in the first equilibrium formula $\left(i\right.$ in $c_{1}$ ) is not unique, but corresponds to a group of various rates of interest and other heterogeneous credit conditions (term, etc). This means that a same equilibrium rate of interest is compatible with differentiate connections between rates and credit conditions. Therefore these connections define an "indifference field", where the determination of monetary equilibrium is theoretically indifferent. More precisely, within the field, some "indifference regions" can be recognized by their set of specific conditions connected with a structure of variables compatible with the monetary equilibrium. These regions are defined by:

- the structure of interest rates and credit conditions which depend on the institutional and political set-up. For instance the separation between the variables under public control and the incontrollable variables among the different combinations of interest rates and credit conditions is different in liberal tradition countries or economic planning tradition countries. Only the controllable variables define the means of monetary policy. For instance, concerning the monetary policy, the scope of an indifference region is not as broad in a classical international gold standard system as in a planning economy with an active Central Bank.

- the balancing function of different elements, non automatically joined with the monetary policy, and capable of maintaining a new monetary equilibrium. For instance, Myrdal

\footnotetext{
${ }^{45}$ These chapters are systematically neglected in all the comments of Myrdal's monetary analysis, even if they claim continuing the 1930 issue (see explicitly 1939: 201 and 205). That filiation is a focal point of our interpretation.

${ }^{46}$ See the title of this chapter: "Monetary equilibrium as a norm".
} 
suppose a restrictive situation: he defines a situation where i) the only controllable variable is the Central Bank discount rate, ii) the different credit conditions are fixed relative to one another in a Standard Combination (they can only change together in a particular direction, and there is no indifference field within the rate of interest), iii) initially the second equilibrium condition is realized $\left(R_{2}=W\right)$. Now suppose a tightening of credit conditions (increasing of the monetary interest rate $i$ ). In this case, Myrdal shows there is still an indifference region. In fact, the sequence defined by a Wicksellian depressive process is initialized: a tightening of credit conditions, a fall in the value of real capital comparing to its production cost $\left(c 1<r 1\right.$ ), hence a decreased profit margin (so a shrinking of $R_{2}$, capital values of real capital, representative of Investment), depressed incomes, first in the capital goods industries, then in the consumption goods industries; the demand for consumption goods declines, with a new fall in capital values (due to a fall in the entrepreneurs anticipated future income)... and so on. But the effectiveness of this depressive process depends again on institutional and political circumstances: rigidity prices to a fall (especially wages), and habits and social legislation to maintain or not money consumption demand (and so to sustain the prices of consumption goods). So, these elements can maintain monetary equilibrium despite the tightening of credit conditions ${ }^{47}$. Elements other than monetary policy are mutually compensating to stay in a monetary equilibrium position. Therefore the monetary policy (here restrictive credit conditions) would be ineffective because a new equilibrium position is possible despite of it (some indifference regions exists), and the cumulative process is stopping ${ }^{48}$. In this case we cannot prove that the resistance of monetary equilibrium is due to monetary policy.

At this first level of the reasoning, to Myrdal, we remain in the positive field of the pure monetary theory (with logical reasoning between causal and final connections), even if, within this theory, we find an area for institutional and political variables (to define indifference regions). There is no value judgment here but only a theoretical analysis with its different hypothetical consequences, with "abstract premises of a factual character in a purely theoretical argument" (1939: 177). At this level, it is impossible to break the deadlock of many indifference regions and to define a concrete practical monetary policy.

On a second level, Myrdal examines monetary equilibrium as a "norm" for monetary policy. To this end, he is introducing iteratively four premises through a process we describe now.

The first premise is the value-premise. The norm has indeed a theoretical and statistical basis in relation with the definition of the monetary equilibrium (with its three conditions and its indifference field and indifferent regions); it has also a normative expression now studied in its relation to the initial theoretical-empirical basis. From this point of view, Myrdal finds again the Swedish inheritance. Wicksell has established a theoretical norm on the correspondence between the natural rate of interest and the money rate of interest,

\footnotetext{
${ }^{47}$ Myrdal indicates that the new equilibrium position would imply an unemployment especially in the capital goods industry.

${ }^{48}$ The same is true if we look at a number of other elements, for example non isolated economy, with international trade (1939: 170 and following). Another indifference regions then spring up.
} 
with its practical equivalence: the price level stability, but he has mixed up a logical issue with a normative issue ${ }^{49}$; in Davidson's works, the norm is a general price level accounting changes in productivity (i.e. the price level should vary inversely to productivity changes). But unlike his predecessors Myrdal wants absolutely an explicit and separate definition of the normative status (in the meaning of political values) involved in a practical norm of monetary policy. Then Myrdal brings the whole issue of the value judgments, which have to be treated as value premises (may be with the mentioned issues concerning the interpretation of non-cognitivist thesis). Only an explicit introduction of the political value judgments in the Myrdalian scheme of iterative selection will permit to define step by step a practical norm of monetary policy and to restrict the indifference field. A constant money value norm can be admitted or, as Myrdal's proposition, a norm of elimination or diminution of the fluctuations of the business cycle, but it is necessary to distinguish the first theoretical-statistical level from the second normative ones ${ }^{50}$, before bridging them with specific notions. At this time the relative choice of the premise value connected with the norm (the mitigation of cycles) is not clearly justified by Myrdal ${ }^{51}$, but his goal is to show the nature of the links between end and means when the norm is admitted with its explicit associated values. Therefore Myrdal admits a priori the norm of mitigation of business cycles corresponds to an harmony of interests (1939: 180). This choice corresponds to an operational simplification, but also to a 1930 procedure: a selection of "actual and present" value judgments to avoid a general relativism of values.

In this attempt, even with the defined norm, and to order to simplify his reasoning, Myrdal is forced to eliminate some sequences ends-means-by-effects and to reduce the number of occurrence. Thus he introduces a second premise. He mentions then it is possible the first choice on value premise is joined with a "factual premise: a theoretical assumption that the realization of the monetary equilibrium is a contribution toward the goal of the realization of cycle attenuation. It is a "premise" because the notion of indifference field connected with a theoretical definition of the monetary equilibrium remains open the compatibility of a monetary equilibrium with a beginning of a cycle (especially changes in prices, in produc-

\footnotetext{
49 "In fact he accepted the comfortable formula of a constant price level more by sentiment and as a result of a normative, a priori, intuition... All this is of course very poor logic..." (1939: 128)

${ }^{50}$ The controversy between Davidson and Wicksell from 1899 to 1922 concerning a defence of a stable price level is partly driven by value judgments which are closely linked with the ideal of justice in the income distribution issue. As indicated by Myrdal (1930), those value judgments are not made explicit and they are not expressed in terms of "value premise" which melt ends, means and by-effects (for instance, in the controversy, purely distributive grounds sometimes appeared to be an expression of the stabilization of the value of money). Above all, they are not located at the right level: only theoretical and statistical analysis is necessary. Even if Davidson is not wrong to involve productivity, it is the theoretical and empirical discussion about the third condition modified by Myrdal that addresses the problem, and not the introduction of a value (justice): "in a scientific analysis, it is perfectly possible in theory to keep the productivity formula free of it" (1939: 141). The methodological coincidence between Davidson's norm and Myrdal's norm is a result of a very different reasoning. Concerning this coincidence, see Hammarskjöld (1955) ; concerning Myrdalian money and income distribution analysis, but without value problem examination, see Trautwein 2011.

51 "I will not pause here over this point, but for the sake of argument I will postulate that the elimination of the cycle is really in the general interest". (1939: 180)
} 
tion and in employment): therefore maintaining monetary equilibrium does not necessarily mean eliminating business cycles. It is a "factual" premise because to Myrdal it does not mobilize value judgments, but lays on theoretical and statistical elements (anticipated by Wicksell with the cumulative process) that a non deviation from monetary equilibrium is the first step to mitigate a cycle. So monetary equilibrium become textitdesirable.

Despite of that double selection, the norm yet remains indeterminate, because, as we have seen, it admits of various solutions: the indifference field of monetary equilibrium plays again a role. Indeed there are many combinations of credit solutions (structure of interest rates) that are compatible with monetary equilibrium. As in his 1930 work, Myrdal mentions that these combinations are in line with an institutional and political set-up, i.e. the different interests of diverse social groups. Myrdal then introduces his third premise: a premise of credit combination. He mentions again his hypothesis of social harmony and he states that in some institutional-political set-up a conventional "standard combination" (1939: 182-183) would be found which would fix a "rule" 52 of variation of the internal relations between components of structure rate (inside the complex $i$ ). The indifference field would be reduced with that ideal model.

With this iterative framework with several routes, Myrdal needs again to introduce new institutional and political hypothesis to accept an "isolation" of monetary policy from other economic policy (interrelations of social, financial policies with monetary policy): his fourth premise is the "isolation premise". Various combinations of policies can produce monetary equilibrium. These combinations are different according to different social groups and their different interests. To Myrdal, the "isolation" of a monetary policy, with its method and content, is particularly dependant on the political struggle: "in an economy in which a socialistic centralization of all economic policy has not yet been carried through, an "isolation" of monetary policy from other economic policy exists as an institutional fact" (1939: 185). It is this premise that Myrdal adopts. While retaining the framework of a fixed standard combination (third premise), it is possible to finish the iterative process of indifference region screening, and to delimitate the means of the monetary policy (in the case chosen by Myrdal). For instance, if $r_{1}$ raises (due to legislation, social insurance), a direct action on $c_{1}$ (with $i$ ) will permit to adapt $c_{1}$ to $r_{1}$ and maintain the monetary equilibrium on capital market $\left(R_{2}=W\right)$.

Now with the four iterative premises, the monetary policy is fully determined: no other policy is possible. For instance, because our assumption of isolated monetary policy and control only on credit conditions, Central Bank cannot influence $r_{1}$, unless we forget the monetary equilibrium and we give up the initial norm. Naturally if the Central Bank is empowered to adapt $c_{1}$ to the raise of $r_{1}$ in sequence, inflation risk is present, with a compatibility with the preservation of the monetary equilibrium. Then Myrdal shows that, if that inflationist consequence is undesirable, it will be necessary to move beyond the norm

\footnotetext{
${ }^{52}$ The rule hypothesis is justified by Myrdal on grounds of arbitration among social groups, and not essentially on grounds of credibility of economic policy (contrary to what Lindahl argues and later modern monetary rules theorists will develop). Moreover Myrdal notes that the rule will always lead to discrimination due to the changes of the value of monetary rate of interest (1939: 183). An example of rule evoked by Myrdal is the international gold standard (with a very limited monetary policy).
} 
of the monetary equilibrium, (and therefore beyond the attenuation of cycles norm). One observation must be underscored: "a theoretical conflict, under the existing political and institutional circumstances, between business stabilization and price stabilization (1939: 191). In this specific context, the two norms are contradictory ${ }^{53}$.

On a last level (1939, chap. IX), Myrdal rightly inquires into the meaning of the reference to the monetary equilibrium, i.e. he examines the normative content of his basic theoretical model (the first level): What are the general assumptions that underlie this equilibrium hypothesis? That shows that Myrdal is on the brink of a radical questioning of the ends-means framework he has previously distorted. In fact he is cautious about this final move. However two elements are invoked. Firstly, the choice of the monetary equilibrium as a basis for the Myrdalian theoretical framework depends on the initial Wicksellian references; so the "immanent criticism" was made inside of this restricted framework. To Myrdal the logical work on this framework is important but the analysis of different practical applications is still limited (what is implicitly means that norm questioning remained incomplete). Secondly the theoretical framework depends on general hypothesis, especially on the hypothesis of rational behavior ${ }^{54}$ (for instance entrepreneurs are maximising their profits and are reacting to a change of the money rate of interest according to this behavior). Myrdal asks whether it is possible to dispense with that hypothesis interpreted as a metaphysical rationalization (i.e. a non real logical consequence of theoretical analysis) questioned in 1930 book:

"Why not accept this directly as simply a statement about people's behavior under capitalist institutions?... Why not start immediately on the same empirical basis as practical "business economics"?" (1939: 205)

Therefore this last level of analysis gives a role to the value judgments inside the core theory previously protected by Myrdal in his first level. It complicates the interpretative and practical framework by opening new sequences of analysis and comparisons upstream of the reasoning. When at the end of his final stage of research Myrdal comes to question the original hypothesis that justify a scientific sequence and implicate some value judgments, he seems to call some intuitive procedures similar to those used by business men when they try to have a coherent picture of a concrete economic situation (previously mentioned in 1931-1933 papers). He suggests a selection procedure for these basic hypothesis:

\footnotetext{
${ }^{53}$ We note the notions of contradiction and compatibility introduce a logical dimension into the Myrdalian treatment of a norm. Myrdal also examines other norms of monetary policy (stabilization on sticky prices, maximum employment of the means of production) and studies the compatibility with the monetary equilibrium (1939: 195-202).

${ }^{54}$ Three other hypothesis are analysed: the "free competition" hypothesis, the separation between short run and long run effects, and the international complications. Concerning these three points, Myrdal argues the improvements he introduced on the Wicksellian framework (for instance differences in the combinations of credit conditions, or differences in the price rigidities, with a monopolistic institutional framework) can go beyond traditional limits while maintaining the reference to the monetary equilibrium. In some cases, amendments introduced to the model would be adequate.
} 
"This procedure beyond the ends-means schema would be largely intuitive and would call the artistic imagination. Our objective is to achieve, after careful psychological studies of as many groups as possible, certain total psychological co-ordinations, similar in nature to the co-ordinations that constitutes personalities, and to use these intuitively to set the sights of scientific analysis. This is how in fact the economist proceeds in his discussion of the practical affairs of the day" (1931-1933: 229).

That procedure is one that would define the role of a necessary technology of economics, but could not be based on logical linkages.

In his most theoretical work, Myrdal thus applies his initial methodological distinction borrowed from Hägerström. By doing so, he is forced to state explicitly a normative premise. This premise must not be "rationalized" (in the Myrdalian sense of induced theory): for instance the smoothing of cycles should not embody any reference to the "natural" feature of cycles as defined by the liberal "doctrine", which uses a "day" versus "night" analogy to offer a mechanical vision of cycles (1939: 201-202). The notion of norm is very specific here: it has a different significance than the one criticized in 1930 (norm per se). It has nothing to do with the descriptive part of the scientific work influenced by false 'doctrines (the blurred frontier between economics and politics). Here, a norm is a bridge between economic theory and political theory based on the introduction of new intermediate notions. The current notion of norm is partly attached to scientific theory, and partly to a judgment of value. It allows for a range of concrete economic prescriptions depending on the structure of interests in society and the institutional structure. The end-means framework is modified by a role of an explicit value judgment identified on each element (and not only on ends). Even if we admit the theoretical and descriptive model, a field of different theoretical solutions is compatible with it. The progressive framing of a concrete monetary policy necessitates other new sequential choices, from four premises, in order to restrict the indifference field and the indifference regions that depend on it. Thus, Myrdal introduces a successive process of elimination of different possible sequences endsmeans, in connection to institutional and political structures. To advance his project, he has to retain only some value premises and factual premises and institutional and political circumstances. But, if he assumes the hypothesis of the harmony of interests (and unique value), the sequences even remain numerous, and the comparisons are incomplete.

\section{Conclusion}

Based on the initial works of Myrdal, it has been shown why the usual split between normative and positive economics was not sufficient to tackle the relations between value judgments and economic policy. A line of thought seemingly makes Myrdal a thinker of the strong neutrality thesis to a supporter of a strong non neutrality thesis: in fact, a precise

analysis focused on two essential moments within that line (1930 and 1939) shows that 
Myrdal's project continues to legitimate a common field between economics and politics. Myrdal actually attempts to produce both a clear distinction between value judgments and science and to bridge the gap between economics and economic prescriptions, and politics. This is why he is led to decompose more subtlety the early notions of positive economics and normative economics, and even to seriously reconsider the distinction between ends and means, with a range of intermediary notions, namely: "technology of economics", "interests", "institutional set-up", "value-premise", "factual premise", "indifference field", "indifference regions" and "norms". In that sense, he redefines more rigorously the partition between science and value judgments (even if he maintains a scientific field of pure theory abstracted from any judgments, except in some closing remarks ${ }^{55}$ ). This project, whose foundations were laid as soon as 1930, also applies to his most theoretical work on monetary economics and monetary policy. This is why Myrdal represents a decisive positioning in history of economic thought when it comes to the relationships between value judgments and economic policy. His notion of monetary norm will set the stage for the connections between monetary macroeconomics and modern macroeconomic policies: the treatment of monetary norms will be made under more technical shapes (Svensson, $2005^{56}$ ) but often less careful than the ones proposed by Myrdal. Especially we note that to Myrdal, a publicity and credibility requirement for the chosen norm is not essential and remains formal from a normative point of view: it is the precise determination of the normative content of the norm and its connections with the theoretical and statistical content that are important. Myrdal confirms again his specific position regarding Lindahl's views (and regarding the modern monetary macroeconomics which focus on publicity, credibility and predictability of the monetary rules). Political value judgments analysis are essential in the determination of a monetary policy, inside a modified ends-means scheme.

Thus Myrdal s attempt to elaborate an apparatus to order to face the value judgment issue concerning practical economics and economic policies must be recognized. But in the result we note that his perspective did not really succeed, unlike Lindahl's ones. Indeed concerning the norm of monetary policy in macroeconomics Lindahl's filiation is notable (Fregert, 1993), even if the role of the value judgments is poorly investigated until it almost disappears from 1924-1930 texts to 1939 English version ${ }^{57}$. Reasons for Myrdal's

\footnotetext{
${ }^{55}$ This point will be questioned during the so-called institutionalist period, starting from the end of the 1930s and especially 1944. In our judgment, it will however be associated with a dramatic weakening of the articulations between economic theory and economic policy (especially monetary policy). We do not evoke this evolution deliberately. From 1944, Myrdal stops using a selection of "economic variables and elaborates a global schema of interaction between "social" variables. The specificity of a technology of economics vanishes.

${ }^{56} \mathrm{Judgments}$ are defined by Svensson as "information, knowledge, and views outside the scope of a particular model" (2005: 2). Therefore judgments are a component of credibility and intertemporal consistency of policy announcements, in a Lindahl's line. Concerning rules and norms in Wicksellian and Neo-Wicksellian monetary macroeconomics, see Barbaroux (2013).

${ }^{57}$ See Lindahl 1939 (part I. §I. The aim of economic theory, and $\S 5$ and 6). We confirm the difference between Lindahl and Myrdal concerning the definition of a norm, with two lines of thought inside the Stockholm School. From his 1924 Ends, Lindahl already focused on the role of a clear goal for monetary policy, on the importance of confidence and predictability in economic life, and not on the value judgments.
} 
weak influence include admittedly some weakness concerning his monetary thesis (Palander 1941, Jonung (1991, ed), Siven 2006) ${ }^{58}$. A new context plays also a role: the Great Depression (with a new importance for fiscal policies and for exchange-rate policy with the English currency in 1933), and, the 1940s and 1950s context (with the World War II, then with economic growth and employment as an unique global criterion and welfare value judgment). But in our judgment the main cause lies in the difficulty of Myrdal's perspective itself concerning an explicit integration of value judgments. Firstly the proposed solutions lead to a complex apparatus with a comparative analysis of too many sequences which depend on the value premises and other premises: we are dealing with a vary large tree of end-means-by-effects sequences, even when the harmony of interests (i.e. a common value) is admitted. The tree complexity would encore be larger if the divergence between the interests of social groups would be taken into account (each of which has specific values, with diverse combinations) As a result Myrdal has to restrict the values choice, or has to adopt a set of fundamental values (the values actually present as a starting point). Secondly it is undoubtedly a sensitive subject for a non-cognitivist framework connected with Hägerström's philosophy to reconcile a dichotomy between science and values with an answer to that fundamental question: how economic science can become politically relevant? The intricate interpretation of Hägerström's emotivism and non-cognitivism raised some recurring issues that also affect the Myrdalian framework, especially concerning the applicability of the true/false criterion to an ends/means schema, to a theoreticalempirical/practical distinction, and also concerning the transposition of the legal concept of "norm to economic policy.

Despite these difficulties, the most interesting in Myrdal's works remains the explicit introduction of value judgments, the defence of the autonomy of politics and the creation of some intermediary concepts to distort or even to overcome the end-means framework and the strict partition between the so-called positive/normative economics. From this point of view, we have not to forget Myrdal's legacy for studying economic policies.

\section{References}

Asso P. F., Leeson R., 2012, Monetary Policy Rules: From Adam Smith to John Taylor, In Koenig E.F., Leeson R., and G.A. Kahn (eds.), The Taylor Rule and the Transformation of Monetary Policy, Stanford, Hoover Institution Press (chap. I, 3-62).

Angresano J., 1998, The Political Economy of Gunnar Myrdal. An Institutional Basis of the Transformation Problem, Edward Elgar, Cheltenham, Lyme.

Atkinson A. B. , 2009, "Economics as a Moral Science", Economica, 76, 791804 (see also in Cowell F. and Witzum A. (ed.), 2007, Lionel Robbins'essay on the nature and significance of economic science. 75th Anniversary Conference Proceedings, London School of Economics and Political Science, London, STICERD, 38-56).

His Wicksellian value judgment "stability is desirable" is only implicit.

${ }^{58}$ These scholars insist on the necessity of: a reasoning not at one point of time, but with a time period of finite length ; of a reasoning on marginal values, and not average values to understand investment behavior ; of consideration of the demand for and supply of money ; of a theory of formation of expectations ; on a more comprehensive connection with a theory of determination of aggregative output and employment 
Backhouse R., 2005, "Economists, values and ideology: a neglected agenda", Revue de Philosophie économique, 11, 31-55.

Barbaroux N., 2013, Monetary Policy in Theory and Practice: facing internal vs external stability dilemma, London, Routledge, Series: International Studies in Money and Banking, to be published.

Barber WJ, 2008, Gunnar Myrdal: An Intellectual Biography, Palgrave Macmillan.

Baujard A. 2012, "Value judgments in economic expertise", Conference, Virginia-Tech, Feb.

Bellet M., Gloria-Palermo S., Zouache A. (eds.), 2004, Evolution of the Market Process. Austrian and Swedish economics, London, Routledge.

Bruun H. H., 2007, Science, Values and Politics in Max Webers Methodology, Hampshire, Library of Congress, Ashgate Pub. Cie.

Cowell F. and Witztum A. (ed.), 2007, Lionel Robbins' essay on the nature and significance of economic science. 75th Anniversary Conference Proceedings, London School of Economics and Political Science, London, STICERD.

Cherrier B., 2009, "Gunnar Myrdal and the scientific way to social democraty, 19141968", Journal of History of Economic Thought, 31(1), 33-55.

Fregert K., 1993, Erik Lindahls norm for monetary policy, in Jonung L. (ed.), Swedish Economic Thought. Explorations and Advances, London, Routledge, chap. 8.

Hägerström A., 1911[1971], Om moraliska forestallningars stanning, translated in On the Truth of Moral Ideas, Inaugural Lecture, Canberra, Department of Philosophy, Faculty of Art, ANU.

1916-39, Inquiries into the Nature of Law and Morals (ed. Olivecrona K., 1953), Almqvist and Wiksells, Uppsala.

Ltd/ Routledge. 1964[2002], Philosophy and Religion, London, George Allen and Unwin

Hammarskjöld D., 1955, "The Swedish Discussion on the Aims of Monetary Policy", International Economic papers, 5, 142-154 (translated from the Swedish, 1944, Heckscher Festschrift).

Hands D. W., 2012, "The Positive-Normative Dichotomy and Economics" in Philosophy of Economics, U. Maki (ed.), Vol. 13 of D. Gabbay, P. Thagard and J. Woods (eds.), Handbook of the Philosophy of Science. Amsterdam, North Holland Elsevier.

Hansson B. A., 1982, The Stockholm School and the Development of Dynamic Method, Croom Helm, London.

Jonung, L., 1979, "Knut Wicksell's Norm of Price Stabilization and Swedish Monetary Policy in the1930s", Journal of Monetary Economics, 5, 459-496.

Jonung L. (ed), 1991, The Stockholm School of Economics Revisited, Cambridge, Cambridge University Press (part IV, What Remains of the Stockholm School? Roundtable discussion).

Joergensen J., 1970, The Development of Logical Empiricism, in Neurath O., Carnap R., Morris Ch. (eds), Foundations of the Unity of Science, University of Chicago Press, vol.II, n1-9: 845-946. 
Laidler D., 1999, Fabricating the Keynesian Revolution. Studies of the Inter-War Litterature on Money, the Cycle and Unemployement, Cambridge, Cambridge University Press.

Lindahl E., 1924, Penningpolitikens mål [Ends of Monetary Policy], Malmö, Sweden, Förlagsaktiebolaget,

Lindahl E., 1930, Penningpolitikens medel [Means of Monetary Policy], Malmö, Sweden, Förlagsaktiebolaget, translated as "The rate of Interest and the Price Level" in 1939, part II.

Lindahl E., 1939, Studies in the Theory of Money and Capital, London, George Allen and Unwin.

Lundberg E., 1974, "Gunnar Myrdal's Contribution to Economic Theory. A Short Survey", Swedish Journal of Economics, 472-78.

Mindus P., 2009, A Real Mind. The Life and Work of Axel Hägerström, Dordrecht, Springer.

Mongin P., 2006, "Value Judgment and Value Neutrality in Economics", Economica, $73,257-286$.

Myhrman J., 1991, The Monetary Economics of the Stockholm School, in Jonung L. (ed.), The Stockholm School of Economics Revisited, Cambridge, Cambridge University Press.

Myrdal G., 1930 [1953], Vtenskap och politik i nationalekonomien, P.A. Nordstedt and Söners Förlag. Stockholm, translated in The Political Element in the Development of Economic Theory. Harvard University Press, Cambridge Mass.

-1931-1933 [1958], "Das Zweck-Mittel-Denken in der Nationalökonomie", Zeitschrift für Nationalökonomie, vol. IV (3), 305-329, translated from the German in Myrdal (1958), Ends and Means in Political Economy, chap.10, 206-230.

-1939 [1965], Monetary Equilibrium, W. Hodge and Company, London, reprint by Kelley New York (from 1931 Om penningteoretisk jmvikt. En studie I den normala rntan I Wicksells penninglärä [On monetary equilibrium: A study in the "normal" rate of interest in Wicksells theory of money], Ekonomisk Tidskrift 33, 191-302 ; and from 1933, Der Gleichgewichtsbegriff als Instrument dergeldtheoretischen Analyse, in Hayek F.A. (ed), Beiträge zur Geldtheorie,Julius Springer, Vienna.

-----1944, An American Dilemma. The Negro Problem and Modern Democracy. Methodological Appendice, New-York and London, Harper.

-----1958, Value in Social Theory. A Selection of Essays on Methodology, Routledge and Kegan, London.

LTD.

Palander T. 1941[1953], "On the Concepts and Methods of the Stockholm School. Some methodological reflections on Myrdals Monetary Equilibrium", International Economic Papers, 3, 5-57.

Petersson B. 2011, "Axel Hägerström and His Early Version of Error Theory", Theoria, 77, 1, 55-70.

Robbins L., 1932, Essay on the Nature and the Significance of Economic Science, London, Macmillan. 
-1963, On the relation between politics and economics, in Politics and economics, London, Macmillan and Co.

Satris, 1982, "The Theory of Value and the Rise of Ethical Emotivism", Journal of The History of Ideas, 43, 109-128.

Schmidt K. J. W., 1995, "Tobins $q$ ? - Myrdals Q! Ein Fallbeispiel fur den Wert von Fremdsprachenkenntnissen", Credit und Capital, 28, 175-200.

Shackle G.L.S., 1967, The Years of High Theory. Invention and Tradition in Economic Thought 1926-1939, Cambridge, Cambridge University Press.

Siven C.-H., 2006, "Monetary Equilibrium", History Of Political Economy 38, 4, 665709.

Stjernberg N.F., 1902, Till frägan om de s.k. rent ekonomiska kategorierna, [On the question of the so-called purely economic categories], Akademisk afhandling, Upsala.

Strang J., 2010, History, Transfer, Politics. Five Studies on the Legacy of Uppsala Philosophy, Academic Dissertation, Faculty of Helsinki, April.

----2007, "Overcoming the rift between is and ought. Gunnar Myrdal and the philosophy of social engineering", Ideas in History, 2(2), 143177.

Svensson L, 2005, "Monetary Policy with Judgment: Forecast Targeting", International Journal of Central Banking, Vol.1(1), May.

Tsinorema S., 2008, Emotivism and Prescriptivism, in G.H.R. Parkinson (ed.) An Encyclopedia of Philosophy, London, Routledge, chap. 27, 613-640.

Syll L. P., 1998, "Myrdal's Immanent Critique of Utility Theory", History of Political Economy, 30 (3), 413-25.

Trautwein H.M., 2005, The loose link: Hayek, Lindahl and Myrdal on money, in Bellet M., Gloria-Palermo S., Zouache A. (eds.), Evolution of the Market Process. Austrian and Swedish Economics, Abingdon, Routledge.

Trautwein H. M., 2011, "From Austrian Economics to the Swedish Welfare State: Wicksellian Views on Money and Income Distribution", Cahiers d'Economie Politique, 61, 51-90.

Weber M., 1922, Gesammelte Aufstze zur Wissenschaftslehre, Tbingen, J.C.B. Mohr (reed. 1985), partial English translation in Shils E.A and Finch H. A., 1949, Max Weber on the Methodology of the Social Sciences, New-York, The Free Press.

Weston S., 1994, "Toward A Better Understanding of the Positive/Normative Distinction in Economics", Economics and Philosophy, 10, 1-17.

Wicksell K. , 1904 [1969]. "Ends and Means in Economics" in Wicksell K., Selected Papers on Economic Theory, ed. E. Lindahl, London, George Allen and Unwin.

Wicksell, K., 1936 [1898], Interest and Prices. A Study of the Causes Regulating the Value of Money, Macmillan and Co.

Wicksell, K, 1967[1901], Lectures on Political Economy, tome 1, Routledge and Kegan Paul LTD, London. 